\title{
Niewydolność serca w przebiegu nieleczonego nadciśnienia tętniczego oraz zaburzeń metabolicznych
}

\section{Heart failure in the course of untreated hypertension and metabolic disorders}

\author{
Elżbieta Piechocka ${ }^{1}$, Joanna Latek-Książek ${ }^{1}$, Małgorzata Woźniak ${ }^{1}$, \\ Robert J. Gil ${ }^{1,2}$, Aneta I. Gziut ${ }^{1}$ \\ ${ }^{1}$ Klinika Kardiologii Inwazyjnej Centralnego Szpitala Klinicznego Ministerstwa Spraw Wewnętrznych i Administracji w Warszawie \\ ${ }^{2}$ Instytut Medycyny Doświadczalnej i Klinicznej Polskiej Akademii Nauk w Warszawie
}

\section{Streszczenie}

Przedstawiono przypadek 38-letniego, dotychczas nieleczonego, pacjenta przyjętego do szpitala z powodu kryzy nadciśnieniowej. U chorego poza nadciśnieniem tętniczym wstępnie stwierdzono chorobę wieńcową, cukrzycę typu 2 i dyslipidemię. Na podstawie koronarografii wykluczono chorobę wieńcową. W rezonansie magnetycznym serca stwierdzono zmiany wskazujące na etiologię metaboliczną niewydolności serca. Po zastosowanym leczeniu hipotensyjnym, hipolipemicznym i diabetologicznym uzyskano poprawę stanu pacjenta, normalizację wartości ciśnienia tętniczego, stężęń lipidów, dobrą kontrolę glikemii oraz poprawę funkcji skurczowej lewej komory.

Słowa kluczowe: nadciśnienie tętnicze, niewydolność serca, cukrzyca, dyslipidemia

Folia Cardiologica 2017; 12, supl. B: B18-B22

\section{Wstęp}

Według definicji Europejskiego Towarzystwa Kardiologicznego (ESC, European Society of Cardiology) niewydolność serca (HF, heart failure) to zespół objawów podmiotowych (duszność, obrzęki kończyn dolnych, obniżenie tolerancji wysiłku), którym mogą towarzyszyć zaburzenia w badaniu przedmiotowym (zastój w krążeniu płucnym, obrzęki obwodowe) [1]. Wynikają one z nieprawidłowości w budowie lub czynności serca powodujących zmniejszony rzut serca i zwiększone ciśnienie wewnątrzsercowe. Poznanie etiologii HF umożliwi najbardziej optymalne leczenie pacjenta. Dlatego istotna jest ocena najczęstszych przyczyn HF choroby wieńcowej, wady zastawkowej, zaburzeń rytmu i przewodzenia, zapalenia mięśnia sercowego czy zaburzeń metabolicznych (cukrzyca, otyłość). W pracy przedstawiono przypadek dotychczas nieleczonego pacjenta, u którego oprócz objawów HF stwierdzono nadciśnienie tętnicze oraz zaburzenia metaboliczne (cukrzyca typu 2, dyslipidemia, hiperurykemia).

\section{Opis przypadku}

Mężczyzna w wieku 38 lat, dotychczas nieleczący się, został przyjęty do kliniki kardiologii inwazyjnej, ze szpitalnym oddziałem ratunkowym, gdzie został skierowany bezpośrednio z gabinetu kardiologicznego z powodu kryzy nadciśnieniowej. Na wizycie ambulatoryjnej pacjent zgłaszał silny ból głowy, przyspieszoną czynność serca, duszność wysiłkową oraz znaczne pogorszenie tolerancji wysiłku. Dolegliwości te występowały od kilku tygodni. W badaniu przedmiotowym stwierdzono tętn6 (HR, heart rate) 120/min, ciśnienie tętnicze (RR) 220/130 mm Hg, zastój w krążeniu płucnym 5 masywne obrzęki kończyn dolnych. Po podaniu 25 mg

Adres do korespondencji: lek. Elżbieta Piechocka, Klinika Kardiologii Inwazyjnej, Centralny Szpital Kliniczny Ministerstwa Spraw Wewnętrznych

i Administracji, ul. Wołoska 137e, 02-507 Warszawa, e-mail: elzbieta.wrobel@gmail.com 


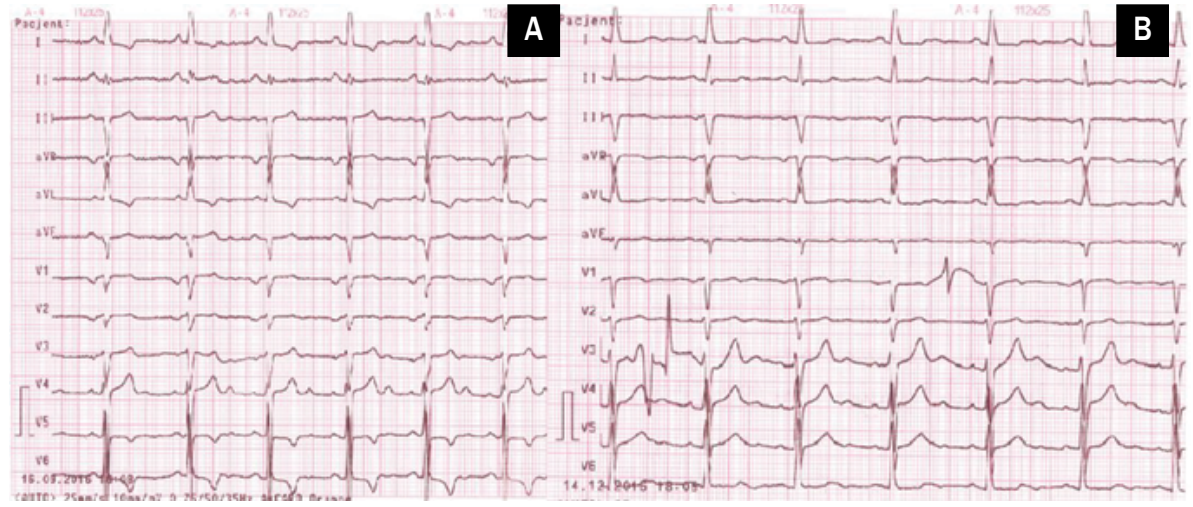

Rycina 1A, B. Zapis elektrokardiograficzny u pacjenta przy przyjęciu do szpitala: lewogram, skośne obniżenie odcinka ST i ujemny załamek T w odprowadzeniach I, aVL i V5-6 (A) oraz po 6 miesiącach stosowanej farmakoterapii - wycofanie się zmian przeciążenia lewej komory (B)

kaptoprilu przewieziono pacjenta do szpitala. Przy przyjęciu do kliniki ciśnienie tętnicze u pacjenta wynosiło 180/110 $\mathrm{mm} \mathrm{Hg}$, a tętno 100/min.

W zapisie elektrokardiograficznym (EKG) stwierdzono cechy przeciążenia lewej komory (ryc. 1A). W badaniu radiologicznym (RTG) klatki piersiowej uwidoczniono objawy zastoju w krążeniu płucnym oraz powiększoną sylwetkę serca (ryc. 2). Natomiast w echokardiografii (ECHO) opisano przerost ścian lewej komory (wymiary przegrody 15/13 mm, wymiary ściany tylnej 14/12 mm), powiększoną lewą komore (wymiary 61/44 mm), hipokinezę ścian lewej komory, frakcję wyrzutową (EF, ejection fraction) równą 30\% oraz podwyższone ciśnienie w krążeniu płucnym (ciśnienie skurczowe prawej komory [RVSP, right ventricular systolic pressure] $57 \mathrm{~mm} \mathrm{Hg}$ ). U pacjenta początkowo włączono furosemid we wlewie (przepływ $6 \mathrm{ml} / \mathrm{h}$ ), perindopril w dawce $5 \mathrm{mg}$, nebiwolol w dawce $5 \mathrm{mg}$ oraz amlodipinę w dawce 5 mg. Obniżono wartości RR. W trakcie hospitalizacji modyfikowano leczenie hipotensyjne, uzyskując poprawę kliniczną (ustąpienie obrzęków kończyn dolnych, zastoju w krążeniu płucnym) oraz optymalizację wartości ciśnienia tętniczego u pacjenta. Stosując $10 \mathrm{mg}$ perindoprilu, 2,5 mg indapamidu, 20 mg nitrendypiny i 50 mg eplerenonu uzyskano prawidłową kontrolę RR. W 24-godzinnym zapisie EKG zarejestrowano trzy epizody przetrwałego częstoskurczu komorowego (nsVT, non-sustained ventricular tachycardia) - z tego powodu odstawiono nebiwolol i włączono bisoprolol w dawce $10 \mathrm{mg}$. By wykluczyć etiologię niedokrwienną uszkodzenia lewej komory, wykonano koronarografię. Nie wykazano w niej zmian miażdżycowych w tętnicach wieńcowych (ryc. 3).

W trakcie hospitalizacji pacjenta konsultowano okulistycznie - rozpoznano cechy angiopatii nadciśnieniowej III stopnia. Na podstawie wyników badań laboratoryjnych rozpoznano cukrzyce (odsetek hemoglobiny glikowanej $\left[\mathrm{HbA}_{1 \mathrm{c}}\right]$ 10,2\%, profil glikemii 213-227-305-224 mg/dl) i zgodnie z konsultacją diabetologiczną włączono leczenie insuliną

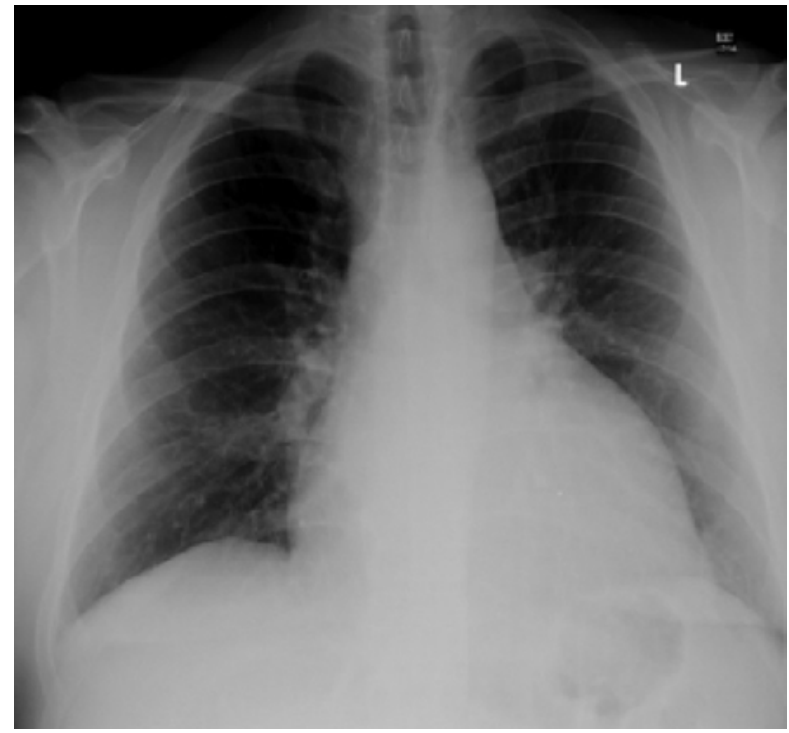

Rycina 2. Obraz radiologiczny (RTG) w badaniu wykonanym przy przyjęciu do szpitala (projekcja tylno-przednia [PA, posteroanterior]) - objawy zastoju w krążeniu płucnym, powiększona sylwetka serca

(łącznie 28 j.) i 150 mg metforminy. Ponadto stwierdzono dyslipidemię (stężenie cholesterolu całkowitego $201 \mathrm{mg} / \mathrm{dl}$, stężenie cholesterolu frakcji HDL [high-density lipoprotein] $25 \mathrm{mg} / \mathrm{dl}$, stężenie cholesterolu frakcji LDL [low-density lipoprotein] $153 \mathrm{mg} / \mathrm{dl}$, stężenie triglicerydów $137 \mathrm{mg} /$ $\mathrm{dl}$ ), hiperurykemię (stężenie kwasu moczowego 9,8 mg/dl), podwyższoną wartość $\mathrm{N}$-końcowego fragmentu propeptydu natriuretycznego typu B ([NT-proBNP, N-terminal fragment of prohormone B-type natriuretic peptide] $5330 \mathrm{pg} / \mathrm{ml}$ ) i niedobór witaminy $D_{3}(10,7 \mathrm{ng} / \mathrm{ml})$. Nie wykazano cech uszkodzenia nerek (stężenie kreatyniny 1,12 mg/dl). Wykluczono wtórne przyczyny nadciśnienia tętniczego. Zalecono atorwastatynę w dawce $10 \mathrm{mg}$, allopurinol w dawce $100 \mathrm{mg}$, suplementację witaminy D oraz modyfikację stylu życia 


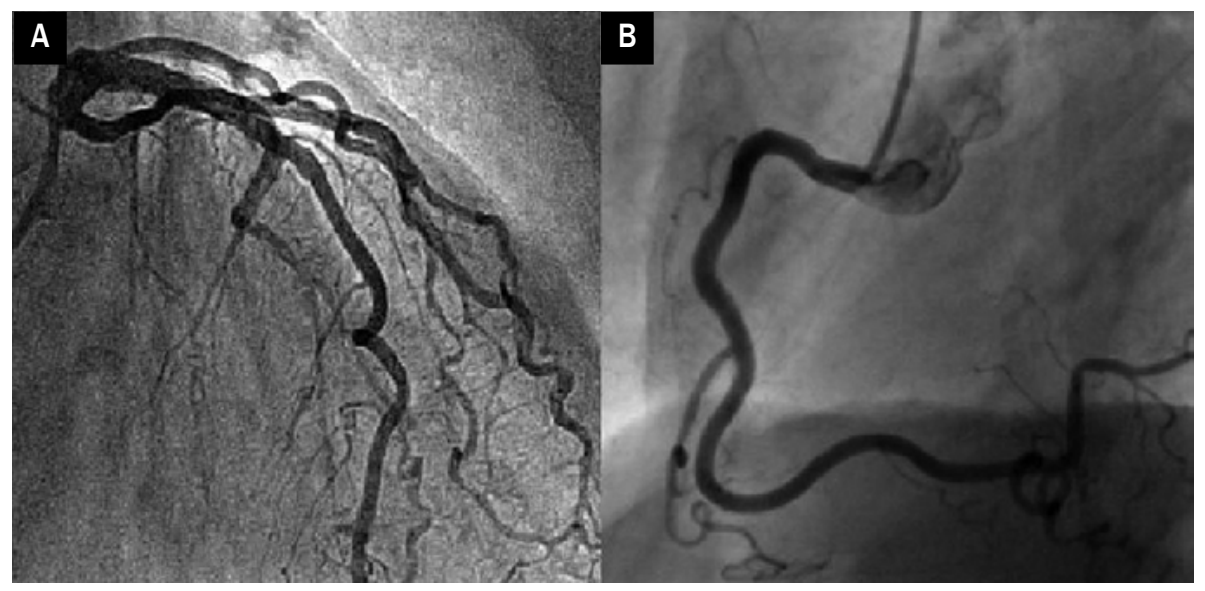

Rycina 3A, B. Prawidłowy obraz tętnic wieńcowych w koronarografii
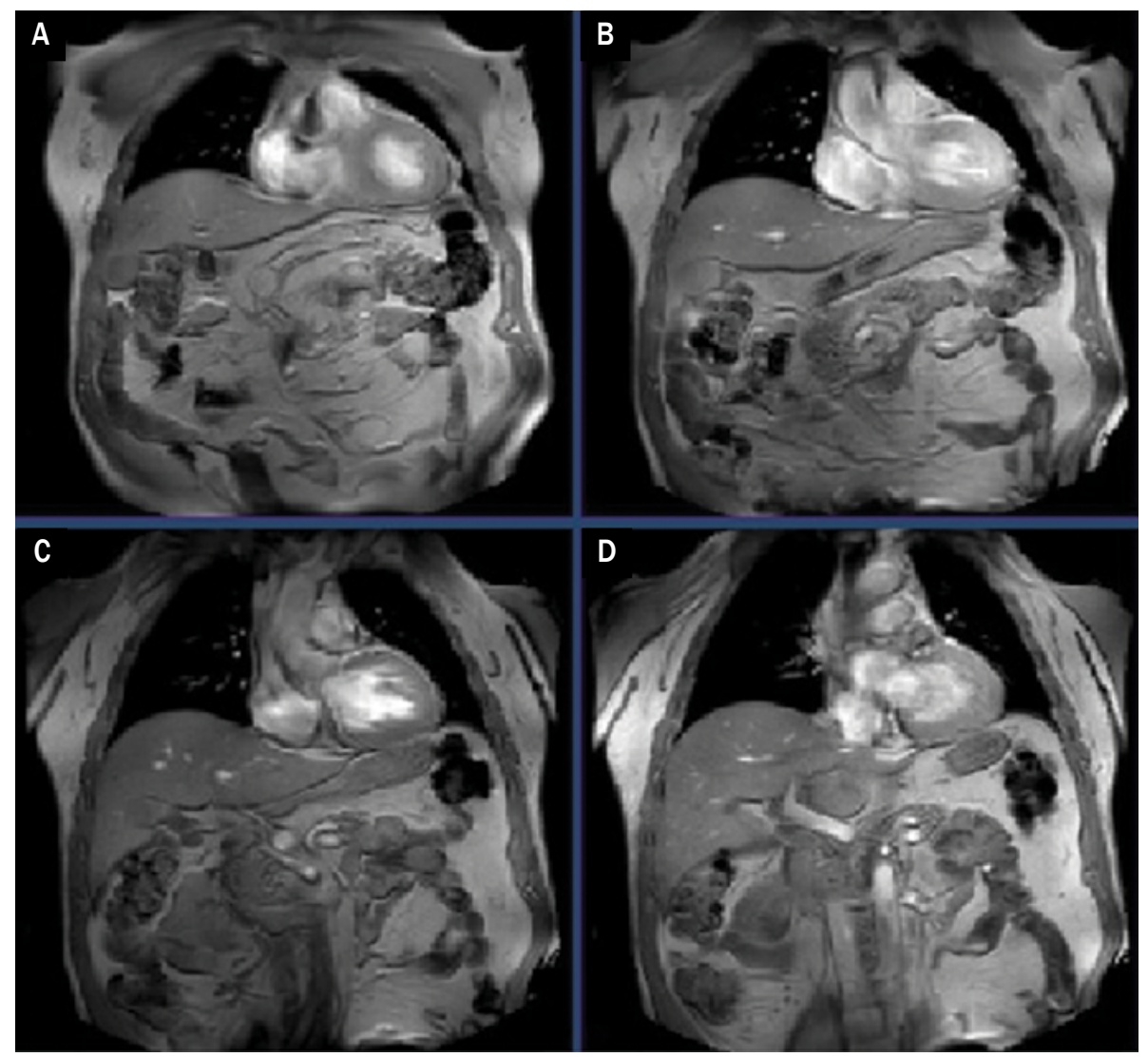

Rycina 4A-D. Rezonans magnetyczny serca wykonany 6 miesięcy po rozpoznaniu niewydolności serca - w okolicy koniuszka uwidoczniono 35-milimetrowy odcinek pełnościennego wzmocnienia kontrastowego oraz małe ognisko późnego wzmocnienia kontrastowego w warstwie podnasierdziowo-śródściennej na pograniczu części dolno-bocznej koniuszka

(zmniejszenie masy ciała - aktualna wartość wskaźnika masy ciała [BMI, body mass index] wynosiła $36 \mathrm{~kg} / \mathrm{m}^{2}$, stosowanie diety cukrzycowej i regularną aktywność fizyczną).

Podczas wizyty kontrolnej (3 miesiące po rozpoczęciu leczenia) stwierdzono tendencję do niskich wartości RR (w pomiarach domowych średnio 110/70 mm Hg, w pomiarze gabinetowym 115/70 mm Hg) oraz tętno równe 65/min. W EKG ujawniono ograniczenie zmian przeciążenia lewej komory (ryc. 1B), natomiast w ECHO serca - poprawe funkcji skurczowej lewej komory (EF 45\%), zmniejszenie wymiarów lewej komory (58/40 mm) oraz ciśnienia w krążeniu płucnym (RVSP $40 \mathrm{~mm} \mathrm{Hg}$ ). Od czasu hospitalizacji 
pacjent schudł $10 \mathrm{~kg}$; stosuje zaleconą dietę i 4-5 razy w tygodniu ćwiczy.

Diabetolog zmodyfikował włączone w szpitalu leczenie - odstawił insuline, metforminę i włączył inhibitor dipeptydylopeptydazy 4 (DPP4, dipeptidyl peptidase 4) - sitagliptynę. Na podstawie domowych pomiarów RR i poprawy czynności skurczowej lewej komory zadecydowano o odstawieniu eplerenonu. W trakcie kolejnej wizyty (miesiąc po modyfikacji leczenia hipotensyjnego) stwierdzono dobrą kontrolę RR (średnio 130/80 mm Hg). W badaniu EKG metodą Holtera nie stwierdzono zaburzeń rytmu i przewodzenia, HR wynosiło średnio 67/min. Postanowiono odstawić bisoprolol i włączyć nebiwolol w dawce $5 \mathrm{mg}$. W kontrolnych pomiarach w warunkach domowych wartości RR wynosiły średnio 125/75 mm Hg, HR natomiast $-75 / \mathrm{min}$. Po tej modyfikacji chory zgłosił poprawe wydolności fizycznej.

Sześć miesięcy po rozpoznaniu u pacjenta wykonano badanie rezonansu magnetycznego (MRI, magnetic resonance imaging) serca (ryc. 4). Wykazano w nim mały obszar zaburzeń kurczliwości lewej komory (hipokineza części przegrodowej i dolnej koniuszka) z EF równą 56\%. W hipokinetycznej części koniuszka zobrazowano 35-milimetrowy odcinek pełnościennego wzmocnienia kontrastowego oraz, dodatkowo, małe ognisko późnego wzmocnienia kontrastowego w warstwie podnasierdziowo-śródściennej na pograniczu części dolno-bocznej koniuszka. Obraz ten przemawiał za etiologią metaboliczną.

W trakcie ostatniej wizyty (7 miesięcy po rozpoczęciu leczenia) stwierdzono dobrą kontrolę RR i HR, chory przestrzega zaleceń dietetycznych, regularnie uprawia sport, łącznie schudł 20 kg i wrócił do pełnej aktywności zawodowej. W kontrolnych badaniach laboratoryjnych wykazano prawidłowe parametry gospodarki lipidowej (stężenie cholesterolu całkowitego $142 \mathrm{mg} / \mathrm{dl}$, stężenie cholesterolu frakcji HDL 40 mg/dl, stężenie cholesterolu frakcji LDL 100 mg/ dl, stężenie triglicerydów $84 \mathrm{mg} / \mathrm{dl}$ ), dobrą kontrolę glikemii (wartość $\mathrm{HbA}_{1 \mathrm{c}} 6,9 \%$ ) oraz prawidłowe stężenia kwasu moczowego (5,8 mg/dl) i NT-proBNP (112 pg/ml). Stwierdzono również zmniejszenie stopnia zaawansowania angiopatii nadciśnieniowej. Obecnie chory przyjmuje $5 \mathrm{mg}$ nebiwololu i preparat złożony zawierający $10 \mathrm{mg}$ perindoprilu, $10 \mathrm{mg}$ amlodipiny i $10 \mathrm{mg}$ atorwastatyny oraz sitagliptynę.

\section{Omówienie}

U pacjenta z objawami HF po wykluczeniu etiologii wieńcowej, zastawkowej czy osierdziowej można dokonać rozpoznania kardiomiopatii [1]. Dzieli się je na pierwotne, kiedy przyczyna nie jest do końca znana (kardiomiopatia zastoinowa, przerostowa, zaciskająca), oraz wtórne (zapalna, metaboliczna, alkoholowa, w przebiegu nadciśnienia tętniczego). U omawianego pacjenta na podstawie badania ECHO i koronarografii nie stwierdzono przyczyny, która mogłaby spowodować uszkodzenie mięśnia sercowego. Natomiast na podstawie wykonanych badań laboratoryjnych rozpoznano zaburzenia metaboliczne - cukrzyce, dyslipidemię. Ponadto u chorego stwierdzono otyłość (BMI $36 \mathrm{~kg} / \mathrm{m}^{2}$ ) oraz nadciśnienie tętnicze. Biorąc pod uwage obraz kliniczny (wybitnie podwyższone RR, nasilone zmiany na dnie oczu, HF) u tego pacjenta należy rozpoznać najcięższą postać nadciśnienia tętniczego, tak zwane nadciśnienie tętnicze złośliwe [2]. Zastosowano leczenie objawowe, dzięki któremu uzyskano ustąpienie objawów HF, obniżenie wartości RR oraz wyrównanie podwyższonych parametrów gospodarek węglowodanowej i lipidowej $[1,3]$. Co istotne, w badaniu ECHO stwierdzono poprawe czynności skurczowej lewej komory i zmniejszenie wymiaru tej komory. Wykonany w 6. miesiącu MRI serca ujawnił tylko nieznaczny obszar zaburzeń w miokardium, którego charakter przemawia za etiologią metaboliczną. Dlatego na podstawie wywiadu, stwierdzonych schorzeń i poprawy funkcji serca po normalizacji RR oraz wyrównaniu zaburzeń weglowodanowych, lipidowych i istotnego zmniejszenia masy ciała - rozpoznano kardiomiopatię wtórną do cukrzycy i nadciśnienia tętniczego.

\section{Konflikt interesów}

Nie zgłoszono.

\section{Abstract}

We present the case of a 38-year-old previously untreated patient admitted to the hospital because of hypertensive crisis. The patient apart from hypertension was initially diagnosed with heart failure, diabetes type 2, dyslipidemia. Coronary ischemic disease was excluded due to angiography. Cardiac magnetic resonance imaging has shown the alternations indicating metabolic etiology of heart failure. After hypertension, hypolipidemic and diabetes treatment, patient's general condition, normalization of blood pressure and lipids values, glycemic control and the improvement of left ventricular systolic function were observed.

Key words: hypertension, congestive heart failure, diabetes, dyslipidemia

Folia Cardiologica 2017; 12, supl B: B18-B22 


\section{Piśmiennictwo}

1. Ponikowski P, Voors AA, Anker SD, et al. [2016 ESC Guidelines for the diagnosis and treatment of acute and chronic heart failure]. Kardiol Pol. 2016; 74(10): 1037-1147, doi: 10.5603/kp.2016.0141, indexed in Pubmed: 27748494.

2. Januszewicz A, Szczepańska-Sadowska E, Prejbisz A. Nadciśnienie tętnicze złośliwe. In: Więcek A, Januszewicz A, Szczepańska-Sadow- ska E, Prejbisz A. ed. Hipertensjologia. Patogeneza, diagnostyka i leczenie nadciśnienia tętniczego. Medycyna Praktyczna, Kraków 2011: 361-363.

3. Tykarski A, Narkiewicz K, Gaciong Z, et al. Zasady postępowania w nadciśnieniu tętniczym - 2015. Nadciśnienie Tętnicze w Praktyce. 2015; 1(1): 1-70. 